\title{
The influence of partial replacement of barley with dietary fat sources on growth and feed conversion efficiency of growing bulls
}

\author{
Alem Tsehai Tesfa, Mikko Tuori and LiISA SyrJälä-Qvist
}

\begin{abstract}
Tesfa, A.T., TuORI, M. \& SYrJÄLÄ-Qvist, L. 1992. The influence of partial replacement of barley with dietray fat sources on growth and feed conversion efficiency of growing bulls. Agric. Sci. Finl. 1: 267-278. (Univ. Helsinki, Dept. Anim. Sci., SF00710 Helsinki, Finland.)
\end{abstract}

\begin{abstract}
This paper presents animal performance and carcass quality in an experiment conducted to observe the effect of replacing some of the barley in a concentrate mixture with different fat sources and wheat bran. The treatments were: concentrate mixture with no added fat (control); in the test feeds, some of the barley was replaced with $5 \%$ of a fat source plus $10 \%$ wheat bran, $1 \%$ wheat molasses and $1 \%$ Ca-lignosulphonate. The fat sources were rapeseed oil (RSO), calcium salt palm fatty acids (CaSFA), or tallow (TS). These four concentrate mixtures were fed to growing bulls with hay (45:55) at a rate of $85 \mathrm{~g}$ dry matter $\mathrm{kg}^{-1}$ metabolic body weight $\left(\mathrm{W}^{0.75}\right)$.

Partial replacement of barley with different fat sources slightly decreased dry matter intake and thereby reduced the daily intake of estimated metabolizable energy in all fat containing diets. Average daily weight gain was $1.20 ; 1.05 ; 1.05$ and $1.08 \mathrm{~kg}$ for the control as to RSO; CaSFA and TS, respectively. Carcass weight was similar for all fat sources but slightly higher for the control diet, while dressing percentage was slightly lower for the control diet. Feeding RSO, TS or CaSFA had no effect on feed conversion efficiency in comparison to the control. No apparent difference was observed between treatments on carcass quality and palatability scores of the meat. Oleic and stearic acids were increased for RSO and TS containing diets as compared to the control and CaSFA containing diets.
\end{abstract}

Key Words: Weight Gain, Longissimus dorsi, carcass composition, Fatty Acids

\section{Introduction}

The effects of adding fat to the diet of ruminants is a complex subject involving the levels, sources and forms of fats as well as their interactions with rumen metabolism. Generally, nutritional benefits obtained from replacing grain with fat are often below the theoretical benefits due to the removal of carbohydrates from the ration. Replacing $30 \%$ of flaked corn with $14 \%$ protected tallow improved the performance of steers in short term feeding (HAALAND et al. 1981), while replacing 8-28\% of corn-grain mixture with $10-30 \%$ protected safflower oil decreased daily weight gain (DINIUS et al. 1975). On the other hand, BoucQue et al. (1990) reported no effect on live weight gain of beef cattle when $17 \%$ of wheat was replaced with $2.5 \%$ or 5.0 $\%$ hydrolysed animal-vegetable fat. Adverse effects of fat on feed intake and feed conversion efficiency have also been reported (HAALAND et al. 1981; OltJEN and DinIUS 1975).

If replacing grain increases energy intake by the animal, the level of animal performance can be increased per cost of gain (feed/weight gain) thus 
improving feed conversion efficiency. The objectives of this experiment were to determine the effect of partial replacement of barley with RSO, TS and CaSFA on feed conversion efficiency, carcass and meat quality of growing bulls.

\section{Material and methods}

\section{Animals}

Twenty eight dairy breed (Friesian-Ayrshire) growing bulls with average initial weights of 123 $\mathrm{kg}$ were randomly allotted into four treatment groups with seven animals in each group. The animals were individually penned and fed the treatments for a period of 256 days. The animals remained on the prescribed treatment until the termination of the experiment except for two animals, one in the control group and the other in the CaSFA group.

\section{Feeds and feedings}

The dietary treatments were: commercial concentrate mixture with no added fat (Control); in the test feeds, part of the barley was replaced by $5 \%$ rapeseed oil (RSO); or $5 \%$ calcium salt palm fatty acids known by the trade name of Megalac produced by Volac Ltd, Cambridge (CaSFA); or $5 \%$ tallow (TS). In addition, the test feeds contained $10 \%$ wheat bran, $1 \%$ wheat molasses and $1 \%$ Ca-lignosulphonate. The forage was timothy ( Phleum pratense) hay. The bulls were fed with $85 \mathrm{~g} \mathrm{DM}$ (concentrate:hay ratio, 45:55 on DM basis) $\mathrm{kg}^{-1}$ metabolic body weight $\left(\mathrm{W}^{0.75}\right)$ given in two equal portions a day. The hay was chopped before it was given to the animals. Water was available freely at all time. A mineral mixture was given at a rate of $100 \mathrm{~g} \mathrm{~d}^{-1}$ throughout the trial. Feed allowances were adjusted every 28 days on the basis of live weight changes.

\section{Digestibility and fermentation study}

A digestion trial was conducted with all the experi- mental animals using acid insoluble ash (AIA) as an internal marker (VAN KeULEN and YoUNG, 1977). Faecal grabs were collected rectally twice daily at 07.30 and $15.30 \mathrm{~h}$ for a period of 7 days at the end of the trial. Daily samples were frozen until the end of collection period. All samples were thawed, mixed and sub-sampled per animal per diet at the end of the collection period.

The gross energy of the feeds and faeces was determined in an adiabatic bomb calorimeter. The digestible energy (DE) of the diets was determined in vivo on the bulls. The metabolizable energy (ME) of the diets was calculated as $81 \%$ of the DE of the diet. The efficiency of feed energy utilization was calculated according to the equations proposed by the Agricultural Research Council (ARC 1980) to estimate energy retained as gain.

The effects of fat sources on rumen fermentation were tested in vitro in a continuous culture fermenter according to MiETtinen and SETÄLÄ (1989). Twenty three grammes of hay and concentrate mixture (50:50) and $5 \%$ of each fat source were fed to the fermentation vessels daily. The fermentation culture was stabilized for 3 days followed by a 2day sampling. The concentrations of the total and individual volatile fatty acids (VFA) were determined.

\section{Weighing and feed sampling}

Upon the initiation of the trial and subsequently at 28 day intervals, the animals were weighed before the morning meal and the weight change of each animal was recorded. Concentrate feeds and hay were sampled every week and pooled for each month.

\section{Chemical analysis}

The chemical composition of the feeds and VFA from in vitro fermentation study were analyzed as explained previously (TESFA et al. 1991a). Faecal and feed samples were analyzed for the AIA (VAN Keulen and Young 1977). 


\section{Slaughtering and sampling}

At the termination of the trial, the final live weight of the bulls was recorded and the animals were slaughtered after $24 \mathrm{~h}$ fasting. Pelvic fat including kidney knobs were totally removed from both sides of the carcasses and weighed. The cold carcasses were weighed and graded visually for fatness and conformation using the five-point scale of the Finnish Slaughter House Classification Scheme. Dressing percentage for each animal and for the group was calculated as a proportion of cold carcass weight to final live weight.

Right half sides of three bulls from each group were randomly selected, cooled for 24 hours at $+4^{\circ} \mathrm{C}$ and measured for specific gravity (sg) in water at $+4^{\circ} \mathrm{C}$ according to KRAYBILL et al. (1952). Empty body weight (EBW) was calculated according to GARRETT and HINMAN (1969) using the equation $\mathrm{EBW}=1.362 \mathrm{X}+30.26, \mathrm{X}$ being carcass weight.

The carcasses were then cut to retail cuts. The rib cuts were marked to obtain samples of longissimus dorsi muscle between the 9-12th ribs and trimmed to determine physically separable fat, lean and bone. The lean part of the section of the longissimus dorsi muscle at the end of the 12th rib was used for the determination of moisture, ether extract, crude protein and fatty acids composition.

\section{Sensory assessment}

Boneless rib roasts from the longissimus dorsi muscle between 9-12th ribs were vacuum packed in polyethylene bags, aged for 20 days at $+4^{\circ} \mathrm{C}$ and were roasted to an internal temperature of $70^{\circ} \mathrm{C}$ in a microwave oven. The roasts were removed from the oven and allowed to stand at room temperature for approximately 15 minutes. A cut of about 1.5 $\mathrm{cm}^{2}$ were served on a preheated plate to an experienced six member sensory panel for assessment of palatability differences. Panellists scored the samples for visual acceptance, tenderness, flavour and juiciness using an eight point hedonic scale.

\section{Instron testing}

Three cooked cuts ( $1.5 \mathrm{~cm}$ diameter) from each carcass were prepared and each cut was sheared once at the right angles of the muscle fibres with an Instron Universal Testing Machine (INSTRON 1140).

\section{Meat chemical composition}

Moisture content was measured by oven drying at $105^{\circ} \mathrm{C}$ for $24 \mathrm{~h}$, crude protein was analyzed by the Kjeldhal method and fat by extracting with petroleum-ether. The lipid portion of the adipose tissue was extracted with chloroform:methanol (2:1 $\mathrm{v} / \mathrm{v}$ ) and an aliquot of the total lipid extract was evaporated under nitrogen. Approximately $100 \mathrm{mg}$ of the total lipid extract was mixed with the internal standard (C12:0 methyl ester) and methylated according to CHRISTIE (1982). Fatty acids methyl esters were analyzed with gas chromatography. The nitrogen carrier gas and hydrogen flow rates were $20 \mathrm{ml} \mathrm{min}^{-1}$ and the air flow rate was $300 \mathrm{ml}$ $\min ^{-1}$. The chromatography was operated with a thermal gradient from $80^{\circ} \mathrm{C}$ to $200^{\circ} \mathrm{C}$ at a rate of $16^{\circ} \mathrm{C} \mathrm{m^{-1 }}$. Peak areas were computed using a microcomputer connected to the chromatography.

\section{Statistical analysis}

The data were analyzed by a one-way analysis of variance with dietary treatment as the only effect and tested with the Tukey test. The dietary effect was further partitioned using orthogonal contrast to test the differences between control and fat sources and between fat sources as follows: control against others, rapeseed oil against CaSFA and TS, and CaSFA against TS.

\section{Results}

The mean chemical composition of the feeds and fatty acid composition of the concentrates offered to the bulls during the trial is given in Table 2. Palmitic acid $\left(\mathrm{C}_{16: 0}\right)$ is considerably higher in CaSFA 
due to its origin from fat. The control diet contained higher concentrations of linoleic acid $\left(\mathrm{C}_{18: 2}\right)$. Stearic acid $\left(\mathrm{C}_{18-0}\right)$ levels were quite similar except for $\mathrm{TS}$. There was a wide variation in oleic acid $\left(\mathrm{C}_{18: 1}\right)$

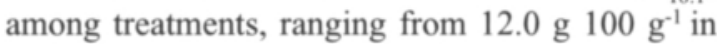

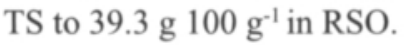

Mean dry matter intake (DMI) tended to decrease with fat inclusion compared to the control. CaSFA

Table 1. Concentrate feed ingredients, $\mathrm{g} \mathrm{kg} 1$

\begin{tabular}{lrrrr}
\hline & \multicolumn{4}{c}{ Dietary groups } \\
& Control & RSO & CaSFA & TS \\
\hline \multirow{2}{*}{ Ingredients: } & & & & \\
Barley & 498 & 328 & 328 & 328 \\
Oat & 250 & 250 & 250 & 250 \\
Soybean meal & 120 & 120 & 120 & 120 \\
Wheat bran & - & 100 & 100 & 100 \\
Wheat molasses & 40 & 50 & 50 & 50 \\
Skim milk & 30 & 30 & 30 & 30 \\
Rapeseed oil & - & 50 & - & - \\
Calcium salt fatty acids & - & - & 50 & - \\
Tallow & - & - & - & 50 \\
Ca-Ligninsulphonate & 20 & 30 & 30 & 30 \\
Mineral mix & 35 & 35 & 35 & 35 \\
Vitamins, ADE & 7 & 7 & 7 & 7 \\
\hline
\end{tabular}

Table 2. Diet chemical composition.

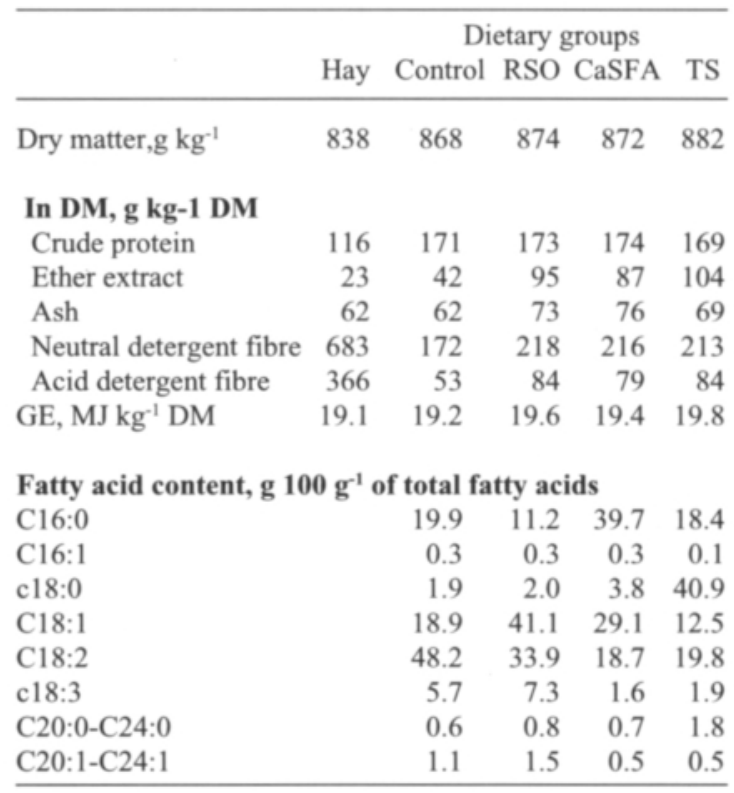

GE, gross energy.

270 and TS fed animals consumed about the same amount (7.1 and $8.2 \%$ less than the control) of DM while the RSO group consumed $13.2 \%$ less than the control group and $6 \%$ less than the two fat groups (Table 3). Fat (from concentrate) intake (g $\mathrm{d}^{-1}$ ) was 113 (control), 241 (RSO), 228 (CaSFA), and 279 (TS). The mean daily intake of neutral detergent fibre (NDF) and crude protein (CP) was

Table 3. Daily feed and feed energy intake by bulls.

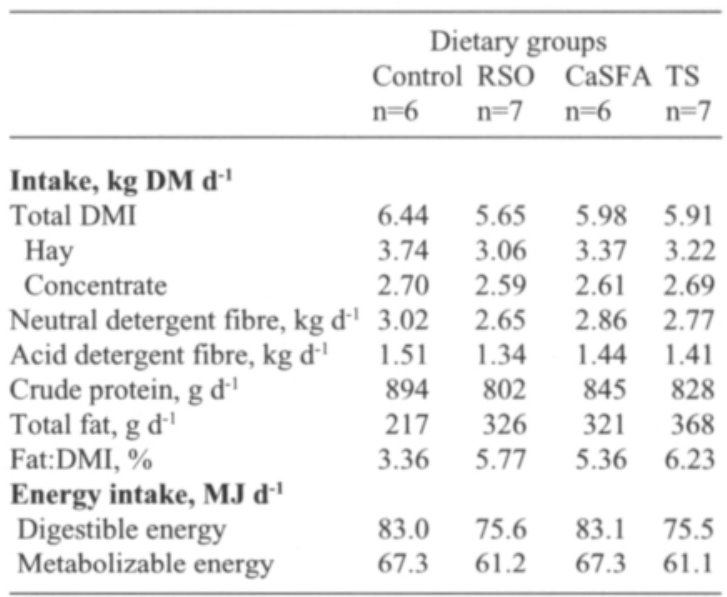

DMI, dry matter intake.

higher for animals fed on the control than fat fed animals whereas ME intake was higher both for the control and CaSFA fed animals.

\section{Nutrient digestibility}

The digestibility coefficients of the diets are given in Table 4. There was no difference $(\mathrm{P}>0.10)$ between the control and diets containing fat or among different fat sources in DM, NDF, acid detergent fibre (ADF) and energy digestibility. CP digestibility was higher $(\mathrm{P}<0.05)$ for $\mathrm{RSO}$ and CaSFA containing diets than the control diet or TS containing diet. RSO and CaSFA had higher $(\mathrm{P}<0.01)$ ether extract $(\mathrm{EE})$ digestibility than TS.

The fermentation pattern from continuous culture 
Table 4. Apparent digestibility of dietary components, $\mathrm{g} \mathrm{kg}^{-1}$.

\begin{tabular}{lccccc}
\hline & \multicolumn{5}{c}{ Dietary groups } \\
& $\begin{array}{l}\text { Control RSO } \\
\mathrm{n}=6\end{array}$ & $\mathrm{n}=7$ & $\mathrm{C}$ CaSFA TS & $\mathrm{n}=6$ \\
& & $\mathrm{n}=7$ & \\
\hline Dry matter & 687 & 703 & 697 & 681 & 21.0 \\
Organic matter & 700 & 716 & 711 & 695 & 20.8 \\
Crude protein & 718 & 743 & 748 & 724 & 23.1 \\
Ether extract & 519 & 724 & 726 & 598 & 38.1 \\
Neutral detergent fibre & 625 & 608 & 633 & 606 & 33.5 \\
Acid detergent fibre & 574 & 559 & 587 & 562 & 38.7 \\
Cellulose & 633 & 618 & 642 & 619 & 36.2 \\
Hemicellulose & 667 & 650 & 674 & 644 & 29.7 \\
Energy & 674 & 692 & 688 & 667 & 22.5 \\
\hline
\end{tabular}

SE, standard error of estimates.

Table 5. The effect of partial replacement of barley with $5 \%$ fat on continuous culture in vitro rumen fermentation.

\begin{tabular}{|c|c|c|c|c|c|}
\hline \multirow{2}{*}{$\begin{array}{l}\text { Dietary groups } \\
\text { VFA mmol l-1 }^{-1} \\
\text { Individual VFA, } \\
\text { mmol mol }^{-1}\end{array}$} & \multicolumn{2}{|c|}{ Control RSO } & \multicolumn{2}{|c|}{ CaSFA TS } & \multirow{2}{*}{$\begin{array}{l}\mathrm{SE} \\
18.09\end{array}$} \\
\hline & 103.5 & 74.4 & 89.0 & 93.9 & \\
\hline Acetate & 638 & 594 & 637 & 633 & 20.3 \\
\hline Propionate & 176 & 255 & 183 & 189 & 46.9 \\
\hline Butyrate & 165 & 132 & 158 & 154 & 27.9 \\
\hline Valerate & 21.9 & 19.3 & 22.3 & 23.7 & 3.51 \\
\hline Acetate/propionate & 3.6 & 2.3 & 3.5 & 3.4 & 0.21 \\
\hline
\end{tabular}

Values for total VFA includes other minor volatile fatty acids.

showed an altered molar proportion of individual VFA with non significant $(\mathrm{P}>0.10)$ differences in total VFA concentration between treatments (Table 5).

\section{Animal performance}

Means for the growth traits are presented in Table 6 . The mean daily weight gain was higher $(\mathrm{P}<0.05)$ for the control group. There was no difference $(\mathrm{P}>0.10)$ in the final live weight of bulls between treatments though the control animals were slightly heavier. However, the control bulls with higher daily weight gains had slightly lower (48.8 vs 49.1 $\mathrm{kg}$ ) dressing percentage compared to the RSO group. Kidney and pelvic fat of the bulls fed on TS and CaSFA increased by $20 \%$ and that of those fed on RSO decreased by $16 \%$ compared to the control. There was no difference in estimated empty body weight or specific gravity of the carcass between treatments.

Dry matter intake per body weight gain was higher (5.72 vs 5.35) for bulls fed on CaSFA containing diet than that of the control diet. The feed conversion rate (ME intake as $\mathrm{MJ} \mathrm{kg}^{-1}$ gain) did not differ between the control, RSO and TS the control bulls displaying a MJ:kg gain ratio of 55.9, and the RSO and TS bulls showing 58.6 and 57.1, respectively. Bulls fed on CaSFA showed the highest consumption of MJ:kg gain (61.2) and lowest partial efficiency of ME in gain compared to others. However, none of these values were statistically significant $(\mathrm{P}>0.10)$.

\section{Carcass quality, shear and taste panel evaluation}

Results of qualitative and quantitative measures of the longissimus dorsi are shown in Table 7. There was no difference among treatments on fleshiness, leanness and round development scores of visual analysis. Sensory panel evaluations of the meat showed that fat feeding did not affect meat palatability or acceptability. The shear force required to cut the meat samples was higher for control animals compared to fat fed animals indicating that meat from animals fed with fat containing diets was more tender than meat from control fed animals.

On the basis of objective measures, separable lean, fat and bone in the $9-12$ th rib cuts showed that the bulls fed on the control diet had higher $(\mathrm{P}<0.05)$ rib cut than TS fed bulls. TS fed animals had a higher $(\mathrm{P}<0.05)$ lean meat and a lower $(\mathrm{P}<0.05)$ fat proportion in comparison to CaSFA fed animals. Apart from the estimated ash content, there was no significant $(\mathrm{P}>0.10)$ difference in chemical composition of the Longissimus dorsi between the dietary treatments. 
Table 6. Effect of dietary fat sources on daily weight gain, carcass merit and feed ME utilization by growing bulls.

\begin{tabular}{|c|c|c|c|c|c|}
\hline & $\begin{array}{l}\text { Control } \\
n=6\end{array}$ & $\begin{array}{l}\text { Dietar } \\
\text { RSO } \\
\mathrm{n}=7\end{array}$ & $\begin{array}{l}\text { CaSFA } \\
n=6\end{array}$ & $\begin{array}{l}\text { TS } \\
n=7\end{array}$ & SE \\
\hline \multicolumn{6}{|l|}{ Body weight, $\mathrm{kg}$} \\
\hline Initial & 123.0 & 123.3 & 123.8 & 123.4 & 28.6 \\
\hline Final & 430.8 & 391.7 & 393.5 & 400.1 & 53.8 \\
\hline Gain, $\mathrm{kg} \mathrm{d}^{-1}$ & 1.20 & 1.05 & 1.05 & 1.08 & 0.122 \\
\hline Carcass wt, kg & 210.5 & 192.9 & 192.8 & 191.7 & 28.4 \\
\hline Dressing percentage & 48.8 & 49.1 & 49.0 & 48.0 & 2.1 \\
\hline \multicolumn{6}{|l|}{ Kidney and pelvic fat, } \\
\hline DMI, $\mathrm{kg}^{-1}$ gain, & 5.35 & 5.40 & 5.72 & 5.45 & 0.57 \\
\hline $\mathrm{ME}, \mathrm{MJ} \mathrm{kg}^{-1}$ gain & 55.98 & 58.61 & 61.26 & 57.14 & 6.29 \\
\hline $\mathbf{k}_{f}^{2}$ & 0.53 & 0.49 & 0.44 & 0.52 & 0.101 \\
\hline Specific gravity ${ }^{\mathrm{n}}$ & 1.067 & 1.081 & 1.070 & 1.073 & 0.008 \\
\hline Carcass, $\mathrm{kg}^{\mathrm{n}}$ & 229.0 & 214.0 & 214.7 & 200.0 & 21.63 \\
\hline Empty body weight, $\mathrm{kg}^{\mathrm{n}}$ & 342.2 & 321.7 & 322.6 & 302.6 & 29.47 \\
\hline
\end{tabular}

DMI, dry matter intake; ME, metabolizable energy; $\mathrm{k}_{\mathrm{f}}^{2}$, partial efficiency of $\mathrm{ME}$ in gain = Estimated energy retention/(ME intake - ME requirement for maintenance (ARC 1980); $\mathrm{n}=$ number of observation is 3 in each group.

Table 7. Composition and hedonic scores of Longissimus dorsi from bulls fed on hay based diets supplemented with different fat sources.

\begin{tabular}{|c|c|c|c|c|c|}
\hline & $\begin{array}{l}\text { Control } \\
n=3\end{array}$ & $\begin{array}{l}\text { Dieta } \\
\text { RSO } \\
\mathrm{n}=3\end{array}$ & $\begin{array}{l}\text { CaSFA } \\
n=3\end{array}$ & $\begin{array}{l}\text { TS } \\
n=3\end{array}$ & SE \\
\hline Rib cut $9-12^{\text {th }}, \mathrm{kg}$ & 13.7 & 11.4 & 11.6 & 10.8 & 1.54 \\
\hline \multicolumn{6}{|l|}{ Proportion of, \% } \\
\hline Separable fat & 20.7 & 20.8 & 20.5 & 14.9 & 3.05 \\
\hline Separable lean & 67.6 & 69.0 & 69.4 & 75.3 & 3.90 \\
\hline Separable bone & 11.7 & 10.2 & 10.1 & 9.8 & 0.35 \\
\hline \multicolumn{6}{|c|}{ Chemical compositions } \\
\hline $\mathrm{pH}$ & 5.5 & 5.5 & 5.6 & 5.6 & 0.05 \\
\hline Water & 71.5 & 73.0 & 72.4 & 72.5 & 1.30 \\
\hline Fat & 7.2 & 4.7 & 6.7 & 5.6 & 2.45 \\
\hline Protein & 19.0 & 20.0 & 19.0 & 20.3 & 2.64 \\
\hline Ash $^{1}$ & 2.33 & 2.33 & 1.95 & 1.85 & 0.18 \\
\hline \multicolumn{6}{|c|}{ Sensory panel score } \\
\hline Juiciness & 3.8 & 4.3 & 4.7 & 5.7 & 1.02 \\
\hline Flavour & 5.3 & 5.5 & 5.7 & 6.0 & 0.61 \\
\hline Panel tenderness & 5.6 & 6.0 & 6.0 & 5.7 & 0.40 \\
\hline Shear force, $\mathrm{kg}$ & 18.8 & 17.6 & 14.2 & 11.8 & 6.91 \\
\hline
\end{tabular}

1. calculated by difference; tenderness, $8=$ very tender, $1=$ very tough; flavour, $8=$ no off flavour, $1=$ tasteless; juiciness, $8=$ very juicy, $1=$ very dry. 
Table 8. Major fatty acid profile of longissimus dorsi from bulls fed on hay based diet supplemented with different fat sources.

\begin{tabular}{|c|c|c|c|c|c|}
\hline & $\begin{array}{l}\text { Control } \\
n=3\end{array}$ & $\begin{array}{l}\text { Dietary } \\
\text { RSO } \\
\mathrm{n}=3\end{array}$ & $\begin{array}{l}\text { CaSFA } \\
\mathrm{n}=3\end{array}$ & $\begin{array}{l}\mathrm{TS} \\
\mathrm{n}=3\end{array}$ & SE \\
\hline C16:0 & 28.10 & 22.10 & 31.12 & 23.66 & 1.482 \\
\hline C16:1 & 2.50 & 2.00 & 3.70 & 2.38 & 0.468 \\
\hline C17:0 & 2.50 & 2.09 & 1.75 & 2.16 & 0.126 \\
\hline C17:1 & 0.56 & 0.42 & 0.49 & 0.55 & 0.037 \\
\hline C18:0 & 23.09 & 25.13 & 20.65 & 26.50 & 2.858 \\
\hline C18:1 cis & 31.43 & 33.56 & 31.73 & 35.54 & 1.001 \\
\hline C18:1trans & 2.77 & 6.22 & 2.68 & 3.22 & 0.639 \\
\hline C18:2n6 & 2.07 & 2.15 & 1.90 & 1.47 & 0.167 \\
\hline C18:2conj. & 0.18 & 0.38 & 0.16 & 0.16 & 0.022 \\
\hline $\mathrm{C} 18: 3 \mathrm{n} 3$ & 0.49 & 0.35 & 0.34 & 0.26 & 0.058 \\
\hline C20:0 & 0.22 & 0.33 & 0.19 & 0.32 & 0.029 \\
\hline Saturated & 53.91 & 49.66 & 53.71 & 52.65 & 1.168 \\
\hline Unsaturated & 40.00 & 45.08 & 41.01 & 43.59 & 2.174 \\
\hline
\end{tabular}

SE, standard error of estimate.

\section{Fatty Acid Composition}

The fatty acid compositions of Longissimus dorsi revealed differences between control and fat sources in the fatty acid profile (Table 8 ). Major differences in fatty acid composition due to fat sources were: decreased palmitic acid $\left(\mathrm{C}_{16: 0}\right)$, increased stearic $\left(\mathrm{C}_{18: 0}\right)$, oleic acid $\left(\mathrm{C}_{18: 1}\right)$ and transisomer of oleic acid on RSO and TS diets. Total saturated fatty acids decreased by $8 \%$ and total unsaturated fatty acids increased by $13 \%$ with RSO compared to the control. The $\mathrm{C}_{18: 1}$ trans acid and conjugated linoleic $\left(\mathrm{C}_{18: 2}\right)$ acids on RSO were high compared to the other dietary groups whereas $\mathrm{C}_{16-0}$ acid was high in bulls fed on CaSFA compared to the other two fat sources.

\section{Discussion}

\section{Feed intake and digestibility}

Total DMI was depressed by replacing barley with fat and the animals fed on RSO and TS diets consumed less ME than the control and CaSFA fed animals. Total DMI may have been depressed simply because the animals fed on fat containing diets tended to sort out the hay while consuming the concentrate feed. This observation is similar to the results of several other studies (BouCQUE et al. 1990; DinIUs et al. 1975) where fat was fed either protected or unprotected to beef animals. When Dinius et al. (1975) replaced 8, 18 and $28 \%$ of corn by 10,20 and $30 \%$ protected safflower oil in the diet of steers, the steers refused to consume the concentrate feed.

Free fatty acids may have organoleptic characteristics which affect feed palatability but the reason for the depressed feed intake with protected fat is not known. Although the RSO and TS used in our trial were not protected from hydrogenation, the bulls consumed fat containing concentrates without any major adaptation problem. No exact physiological reason has so far been proposed for reduced feed intake when fat is included in the ration of ruminants however, rumen infusion of individual and mixtures of VFA in goats and sheep indicated that propionate infusion depresses feed intake more than to acetate and butyrate infusion (BAILE and MAYER 1970). Besides the probable reduction in gastro-intestinal tract movement caused by the free 
fatty acids (NichOLSON and OMER 1983) which tend to delay passage of feed through the digestive tract, an increased proportion of propionate in the rumen due to dietary fat could be another factor for reduced feed intake.

The absence of depressed digestibility of DM, $\mathrm{OM}$ and energy in our trial demonstrates that fat sources, saturated or unsaturated, fed at $5 \%$ of concentrate mixture have no significant effect on non fibre component digestibility. The absence of significant depression in OM, DM and fibre observed with $5 \%$ RSO feeding in this trial is not consistent with the results obtained with fistulated bulls (Tesfa 1991) where the digestibility of all the dietary components was depressed. The discrepancy could be due to differences in the markers used (AIA or Chromium oxide). Using the total collection of faeces, JENKINS and PALMQUIST (1984) observed a depression in DM digestibility when 5 $\%$ added tallow was fed with $50 \%$ hay to steers. MOORE et al. (1986) noted depressed NDF and ADF digestibility with steers fed a forage diet containing $6.3 \%$ cottonseed oil, which is consistent with the result for RSO feeding in this trial.

Calcium soap fatty acids are insoluble at normal rumen $\mathrm{pH}$ and thus inert to fermentative digestion in vitro (CHALUPA et al. 1984). In the abomasum at lower $\mathrm{pH}$, the calcium and the fatty acids dissociate, leaving free fatty acids and calcium ions to be utilized in the subsequent normal digestion and absorption. JENKINS and PALMQUIST (1984) have provided evidence that the feeding of preformed calcium soaps of tallow and soya oil fatty acids to dairy cows allowed normal rumen digestion of the cell wall, whereas, non-saponified tallow fatty acids caused reduced cell wall digestibility. Although fat supplement increases microbial efficiency, calcium soaps however failed to improve microbial protein synthesis when fed to lactating milking cows (JenKINS and PAlmQUisT 1984). Presumably the CaSFA did not inhibit protozoa, both in their and our study, to increase efficiency of microbial protein synthesis for efficient animal performance.

In vitro studies with tallow fatty acids have shown that they have only mild effects on VFA production or on acetate:propionate ratio compared to controls (CHALuPA et al. 1984). The effect of TS on rumen fermentation was mild compared to RSO due to high melting point and saturation level of tallow fatty acids. The overall changes in rumen fermentation observed are consistent with in vivo studies with increasing levels of RSO (TESFA et al. 1991a) and in vitro with corn oil and tallow fatty acid (JENKINS 1987). RSO containing high $\mathrm{C}_{18: 2}$ fatty acids caused a more depressive effect on all fermentation parameters.

The addition of calcium to a high fat diet has been shown to reverse depressed fibre digestibility in vitro (JENKINS and PALMQUIST, 1982) and in vivo with steers (PALMQUIST and JENKINS, 1982). However, in the present study, no improvement was observed in overall digestibility of the diet with CaSFA compared to the other two fat sources. Our data indicates that CaSFA was not totally inert in its effect on the rumen environment.

Dietary fat inclusion in the diet of ruminants increases propionate concentration with simultaneous reduction in methane formation (VAN NEVEL and DEMEYER 1981) and thus increases the metabolizability of the gross energy (WHITELAW et al. 1984). Although, the in vitro results revealed that dietary fat increases glucogenic compound, the efficiency of feed energy utilization by the bulls remained low.

\section{Animal performance}

Marked reduction in feed intake has been the most consistent effect observed with fat containing diets which affects growth rate and animal performance. Although we observed a decrease in daily weight gain, we did not notice any difference in animal performance between fat sources, even with CaSFA, which is supposed to have a mild effect on rumen environment. There are conflicting reports from the literature on the effect of dietary fat on animal growth rate. For example, BouCQUE et al. (1990) reported that replacing $17 \%$ or $33 \%$ of wheat with $2.5 \%$ or $5.0 \%$ blended animal-veget- 
able fat had no effect on daily weight gain of beef cattle. Short term feeding of steers with $14 \%$ or $25.5 \%$ protected tallow replacing $30 \%$ or $57 \%$ of flaked corn was noted to improve animal performance (HAALAND et al. 1981). In contrast to this, Dinius et al. (1975) reported a decreased daily gain with steers when replacing 8-28\% corn-grain mixture with 10-30\% protected safflower oil. Differences in fat source on animal performance has also been reported in the work of BOUCQUE et al. (1990) where $5 \%$ lard decreased daily weight gain compared to $5 \%$ blended animal-vegetable fat.

Supplementing the ration of feedlot steers with 4 $\%$ yellow grease or $4 \%$ blended animal-vegetable fat increased the efficiency of microbial protein synthesis (ZINN 1989) and improved animal performance. In trials where grain was replaced by fat, depressed animal performance seems to be associated with a reduced availability of readily fermentable carbohydrate. A reduced availability of carbohydrates, combined with the negative effect of fat on rumen metabolism, may lead to a shortage of energy for rumen microbial energy generation because fat cannot be fermented (apart from glycerol) by rumen microbes to be used as energy sources. Therefore, even if recycling of nitrogen can be reduced as the effect of fat on rumen protozoa to improve microbial efficiency, replacement of grain with fat does not seem to increase animal performance due to the above mentioned shortage of energy.

\section{Carcass quality}

Meat quality varies from muscle to muscle within an animal. A single muscle, therefore, cannot be representative of the whole animal under all circumstances. In our study, Longissimus dorsi muscle was considered as "representative" of the whole carcass because of its relative uniformity and the fact that the sampling position can be defined exactly by indicating the adjacent vertebrae. Sensory evaluation of the boneless rib roast indicated no major differences in flavour or tenderness. The physical force required to test the tenderness of meat however was high for the control bulls.

Increased carcass fat content (BOUCQUE et al. 1990), as well as increased empty body weight, kidney and heart fat (ZINN 1989) and kidney and pelvic fat (HAALAND et al. 1981) have been reported for animals fed fat supplemented diet or partial replacement of grain with fat. Increasing the level of blended animal-vegetable fat in the diet from 4 $\%$ to $8 \%$ increased the kidney-pelvic fat by $17 \%$ (ZINN 1989). Consistent with ZINN's observation was an increase of $20 \%$ in the kidney-pelvic fat observed with $5 \%$ TS and CaSFA inclusion whereas RSO inclusion decreased it. This difference may indicate that saturated fatty acids stimulate the deposition of pelvic fat more than unsaturated oil sources. TS fed bulls deposited more fat around the kidney and pelvic region and less fat in intramuscular tissue.

\section{Fatty acid composition}

The $\mathrm{C}_{16: 0}$ acid content was decreased by RSO and TS feeding as compared to the control but was high for bulls fed with CaSFA because CaSFA contained higher proportion of palmitic acid and palmitic acid is not sensitive to rumen hydrogenation. The decrease in $\mathrm{C}_{16: 0}$ acid was $21 \%$ with RSO and $16 \%$ with TS feeding. When safflower containing polyunsaturated fatty acids was infused into the abomasum of steers, the $\mathrm{C}_{18: 2}$ content of Longissimus dorsi was increased by 2.4 to $5 \%$ compared to $0.9 \%$ increase when steers were fed orally (DINUS et al. 1974). In the same work, the infusion of oil had no effect on tissue $\mathrm{C}_{18: 1}$. Regarding $\mathrm{C}_{18: 2}$, our results agree with DINUS et al. (1974) and it is probable that this fatty acid, whether fed in the form of oil supplement or as a grain constituent, undergoes complete hydrogenation in the rumen. In practice, the increase in $\mathrm{C}_{18: 2}$ acid in milk or meat creates storage problems due to its sensitivity to oxidative rancidity which produces "oily" flavours (MCDONALD and SCOTT 1977). $C_{18: 2}$ has a low $\left(-5^{\circ} \mathrm{C}\right)$ melting point compared to that of $\mathrm{C}_{18: 1}$ acid $\left(13.4-16.3^{\circ} \mathrm{C}\right)$, and this low melting point affects the firmness of the meat at a particular temperature (Wood 1984). 
The increase in $\mathrm{C}_{18: 1}$ was much higher with RSO feeding contrary to the report of DinIUs et al. (1974) with safflower feeding but in agreement with ROBERT and MCKIRDY (1964), who demonstrated that the feeding of rapeseed oil increased the percentage of monounsaturated $\left(\mathrm{C}_{18: 1}\right)$ fatty acid by $3.5 \%$ in prerenal fat. In contrast to our observation, GARRET et al. (1976) observed a decrease in $\mathrm{C}_{\text {18:0 }}$ and $\mathrm{C}_{18: 1}$ content of Longissimus dorsi from steers fed on a diet containing 15 and $30 \%$ protected vegetable oil. The increases in $\mathrm{C}_{18: 0}$ and $\mathrm{C}_{18: 1}$ acids content with RSO feeding correspond to the increase in these acids observed in milk fat of milking cows fed RSO (TESFA et al. 1991a \& b). According to Dryden and Marchello (1973), the fatty acid content of intermuscular and intramuscular fat of Longissimus dorsi, Semimembranosus and Triceps brachii muscles responded similarly to dietary supplementation of $6 \%$ sunflower oil or animal tallow. The only difference was that animals fed with animal fat had more saturated fatty acids than sunflower oil fed animals.

DRYDEN and MARCHELlo (1970) reported low and variable correlations between fatty acid composition and quality characteristics. However, in studies with steers fed non fat supplemented diets, Westerling and HeDrick (1979), reported a positive correlation between oleic acid and flavour score, suggesting that the concentration of $\mathrm{C}_{18: 1}$ acid has a specific effect on the flavour of the meat. In our study, the panel evaluation did not observed any major difference in the flavour of meat from RSO fed bulls though the $\mathrm{C}_{18: 1}$ acid was high compared to other treatments.

\section{Conclusion}

The current study showed that replacing grain with fat and feeding it with hay tends to depress total feed intake. Although partial replacement of barley with fat had no significant effect on nutrient digestibility, the feed intake of the animal and efficiency of feed conversion by the animals was depressed. Weight gain per feed intake was observed to be low for fat containing diets compared to the control. A lowered growth rate seems to be due to the reduced availability of readily fermentable carbohydrates as a consequence of the replacement of grain by fat. Therefore, although fat increases the energy density of the diet, since it cannot be catabolized in the rumen, the replacement of grain with fat in the diets of growing bulls has no economic benefit.

Acknowledgements. The authors are grateful to Prof. Eero Puolanne, Olavi Törmä, M.Sc. Agric., and the technical staff of the Department of Meat Technology for their advice and assistance in meat quality evaluation. We would also like to express our warm gratitude to Tore Storgårds, M.Sc. Agric., for his excellent technical assistance during the experiment. We also wish to express our sincere gratitude to Seppo Karttunen and the technical staff in Suitia experimental farm for their contribution to this experiment.

\section{References}

ARC 1980. The nutrient requirements of ruminant livestock. Agricultural Research Council. Commonwealth Agricultural Bureaux, Slough, England. p. 351.

BAIL, C.A. \& MAYER, J. 1970. Hypothalamic centres: Feedbacks and receptors sites in the short-term control of feed intake. In: Phillipson, A.T. (ed.). Physiology of digestion and metabolism in the ruminant. p. 254-263.

Boucque, Ch.V., Fiems, L.O. Cottyn, B.G. \& Buysse, F.X. 1990. Effect of dietary fats on animal performance, carcass quality and lipid composition of kidney fat in beef bulls. J. Anim. Physiol. Anim. Nutr. 63: 213-219.

Chalupa, W., Rickabaugh, B., Kronfield, D.S. \& Sklan, D. 1984. Rumen fermentation in vitro as influenced by long chain fatty acids. J. Dairy Sci. 67: 1439-1444.

Christie, W.W. 1982. The procedure for rapid transmethylation of glycolipids and cholesteryl esters. J. Lipid Res. 23: 1072-1075.

Dinius, D.A., OltJen, R.R \& SATter, L.D. 1974. Influence 
of abomasally administered safflower oil on fat composition and organoleptic evaluation of bovine tissue. J. Anim. Sci. 38: 887-892.

-, Edmondson, L.F., Kimoto, W \& Oltjen, R.R. 1975. Growth, blood parameters and tissue lipids of finishing cattle fed a formaldehydetreated casein-safflower oil complex. J. Anim. Sci. 40: 358-365.

DRYDEN, F.D. \& MARChEllo, J.A. 1970. Influence of total lipid and fatty acid composition upon the palatability of three bovine muscles. J. Anim. Sci. 31: 36-41.

— \& MARChello, J.A. 1973. Influence of dietary fats upon carcass lipid composition of the bovine. J. Anim. Sci. 37: 33-39.

GARRETT, W.N. \& HinMAN, N. 1969. Re-evaluation of the relationship between carcass density and body composition of beef steers. J. Anim. Sci. 28: 1-5.

-, YANG, Y.T., DuNKLeY, W.L. \& SMITH, L.M. 1976. Energy utilization, feedlot performance and fatty acid composition of beef steers fed protein encapsulated tallow or vegetable oils. J. Anim. Sci. 42: 1522-1533.

HaAland, G.L., Matsushima, J.K., Johnson, D.E. \& WARD, G.M. 1981. Effect of replacement of corn by protected tallow in a cattle finishing diet on animal performance and composition. J. Anim. Sci. 52: 696-702.

JENKINS, T.C. 1987. Effect of fats and fatty acid combinations on ruminal fermentation in semi-continuous in vitro cultures. J. Anim. Sci. 64: 1526-1532.

— \& PALMQUIST, D.L. 1982. Effect of added fat and calcium on in vitro formation of insoluble fatty acid soaps and cell wall digestibility. J. Anim. Sci. 55: 957-963.

— \& PALMQUIST, D.L. 1984. Effect of fatty acids or calcium soaps on rumen and total nutrient digestibility of dairy rations. J. Dairy Sci. 67: 978-986.

KRAYBILL, H.F., BITter, H.L. \& Hankins, O.G. 1952. Body composition of cattle. II. Determination of fat and water content from measurement of body specific gravity. J. Appl. Physiol. 4: 575-583.

McDonald, I.W. \& ScotT, T.W. 1977. Foods of ruminant origin with elevated content of polyunsaturated fatty acids. World Rev. Nutr. Diets. 26: 144-207.

Miettinen, H. \& SetÄLĀ, J. 1989. Design and development of a continuous culture system for studying rumen fermentation. J. Agric. Sci. Finl. 61: 463-473.

MoOre, J.A., SWInGle, R.S. \& Hale, W.H. 1986. Effects of whole cottonseed, cottonseed oil or animal fat on digestibility of wheat straw diets by steers. J. Anim. Sci. 63: 1267-1273.

Nicholson, T. \& OMER, S.A. 1983. The inhibitory effect of intestinal infusions of unsaturated long-chain fatty acids on forestomach motility of sheep. Br. J. Nutr. 50: 141149.

OltJen, R.R. \& Dinius, D.A. 1975. Production practices that alter the composition of foods of animal origin. J. Anim. Sci. 41: 703-722.

PALMQUIST, D.L., \& JenKInS, T.C. 1982. Calcium soaps as a fat supplement in dairy cattle feeding. Page 477 in Proc.
XII World Congr. Dis. Cattle. Vol. 1. Amsterdam, the Netherlands.

ROBERTS, W.K. \& MCKIRDY, J.A. 1964. Weight gains, carcass fat characteristics and ration digestibility in steers as affected by dietary rapeseed oil, sunflowerseed oil and animal tallow. J. Anim. Sci. 23: 682-687.

SNedeCor, G.W. \& CocheAn, W.G. 1967., Statistical methods. Sixth edition. The Iowa State University Press. U.S.A.

Tesfa, A.T. 1991. Effects of rapeseed oil supplementation on site of digestion, microbial protein synthesis and duodenal amino acid composition. (In press. Anim. Feed Sci. Technol.).

—, TUORI, M. \& SYrJĀLAä-Qvist, L. 1991a. High rapeseed oil feeding to lactating cows and its effects on milk yield and composition. Finn. J. Dairy Sci. 49: 65-81.

—, SYRJÄLÄ-QVIST, L. \& TUORI, M. 1991b. Replacement of grain by tallow or rapeseed oil in the diet of lactating cows and its effects on milk yield and composition. Finn. J. Dairy Sci. 49: 54-64.

ZINN, R.A. 1989. Influence of level and source of dietary fat on its comparative feeding value in finishing diets for steers: Feedlot cattle growth and performance. J. Anim. Sci. 67: 1029-1037.

Van Nevel, C.J. \& DMeYer, D.I. 1981. Effect of methane inhibitors on the metabolism of rumen microbes in vitro. Arch. Tierernăhrung. 31: 141-151.

VAn Keulen, J. \& Young, B.A. 1977. Evaluation of acidinsoluble ash as a natural marker in ruminant digestibility studies. J. Anim. Sci. 44: 282-287.

Westerling, D.B. \& Hedrick, H.B. 1979. Fatty acid composition of bovine lipids as influenced by diet, sex and anatomical location and relationship to sensory characteristics. J. Anim. Sci. 48: 1343-1348.

Whitelaw, F.G., Eadie, J.M., Bruce, L.A. \& Shand, W.J., 1984. Methane formation in faunated and ciliate-free cattle and its relationship with rumen volatile fatty acid proportions. Br. J. Nut. 52: 261-275.

WooD, J. D. 1984. Fat deposition and the quality of fat tissue in meat animals. In: Wiseman, J.(ed.). Fats in Animal Nutrition p. 407-435.

\section{Manuscript received January 1992}

Alem Tsehai Tesfa

Mikko Tuori

Liisa Syrjälä-Qvist

University of Helsinki

Department of Animal Science

SF-00710 Helsinki, Finland 
SELOSTUS

\title{
Ohran osittainen korvaaminen erilaisilla rasvoilla kasvavan lihanaudan ruokinnassa
}

\author{
Alem Tsehai Tesfa, Mikko Tuori ja LiISA SyrjäLÄ-Qvist \\ Helsingin yliopisto
}

Kasvavilla ay- ja fr-sonneilla suoritetussa 256 päivän pituisessa ruokintakokeessa oli 24 sonnia, joiden keskimääräinen elopaino kokeen alussa oli $123 \mathrm{~kg}$. Eläimet olivat rajoitetulla ruokinnalla ja saivat $85 \mathrm{~g}$ kuiva-ainetta metabolista elopainokiloa kohti. Karkearehuna oli heinä, väkirehuna ohra, josta korvattiin osa erilaisilla rasvoilla. Dieetin väkirehukorsirehusuhde oli 45:55. Kontrolliryhmällä väkirehu oli ohraa, RSO-ryhmällä $32 \%$ ohrasta korvattiin $5 \%$ :lla rypsiöljyä, CaSFA-ryhmässä sama määrä ohraa korvattiin $5 \%$ :lla palmuöljyn kalsiumrasvahapposuoloja, ja TS-ryhmässä ohraa korvattiin $5 \%$ :lla talia.
Rasvan sisällyttäminen ruokintaan alensi lievästi rehunsyöntiä ja energiansaantia kaikissa rasvaryhmissä. Dieetin orgaanisen aineen, raakavalkuaisen tai solunseinămäaineiden sulavuuteen rasvoilla ei ollut vaikutusta. Keskimääräiset lisäkasvut olivat $1.20,1.05,1.05$ ja $1.08 \mathrm{~kg} / \mathrm{d}$ kontrolli, RSO-, CaSFA- ja TS-ryhmissä, erot eivät olleet merkitseviä. Myöskään rehun muuntosuhteessa ei dieettien välillä ollut merkitsevää eroa (3.91, 4.20, 4.44 ja 4.33 ry/lisäkasvukg).

Ruhon laatu- tai maittavuusarvostelussa ei tullut eroja dieettien vălille. Longissimus dorsi -lihaksen rasvan koostumus analysoitiin. RSO- ja TS-dieetit lisäsivät öljy- ja steariinihappojen osuutta rasvassa. 